\title{
GLUTAMINE SYNTHETASE-I. A COMPARATIVE STUDY OF ITS DISTRIBUTION IN ANIMALS AND ITS INHIBITION BY DL-ALLO- $\delta$-HYDROXYLYSINE* +
}

\author{
CHUNG WU \\ Department of Internal Medicine, The University of Michigan Medical School, Ann Arbor, \\ Michigan, U.S.A.
}

(Received 27 August 1962)

\begin{abstract}
The optimal conditions for assaying glutamine synthetase activity in tissue homogenates have been investigated.

2. The distribution of the synthetase activity in seventeen species of the vertebrates and one species of Protozoa (Tetrahymena pyriformis) has been studied.

3. The present study shows that a definite correlation exists between the distribution of glutamine synthetase in animals and the phylogenetic classification. (a) The enzyme activity was found in the brain of all vertebrates examined. From the fishes to the ureotelic reptiles, brain was also the only organ where the enzyme activity could be found. (b) The enzyme activity occurred in the liver of all animals from the uricotelic reptiles to the mammals. (c) The enzyme activity was detectable in the kidney of some mammals, in the heart of the birds, and in the pancreas of the uricotelic animals. It was present also in the spleen, lung, and testis of some species of animals. (d) The enzyme activity was not observed, however, in the blood, skeletal muscle, skin, or small intestine of any species used.

4. The significance of the synthetic reaction in the detoxication of ammonia and in the maintenance of balance of the glutamic acid-glutamine system is discussed.

5. The glutamine content in the liver of many species of animals was not related to the synthetase activity in either the liver or the brain of these animals.

6. The protozoan possessed the enzyme activity also.

7. DL-Allo- $\delta$-hydroxylysine inhibited glutamine synthetase activity in a variety of tissues from many species of animals. The inhibition was noncompetitive with respect to glutamate.
\end{abstract}

\section{INTRODUCTION}

GLUTAMINE synthetase, which catalyzes the formation of glutamine, ADP $\ddagger$, and IP from glutamate, ammonia, and ATP (Elliott, 1948; Speck, 1949), appears to have

* A preliminary report of this work was presented at the 51st Annual Meeting of the American Society of Biological Chemists, 11-15 April 1961, Chicago, Illinois, and appeared in Fed. Proc. 20, 218 (1961).

$\dagger$ The work was supported in part by a research grant, C 1719, from the National Cancer Institute, U.S. Public Health Service.

$\ddagger$ The following abbreviations are used: ADP, adenosine diphosphate; IP, inorganic orthophosphate; ATP, adenosine triphosphate; HL, DL-allo- $\delta$-hydroxylysine; BAL, 2,3-dimercaptopropanol; GHA, $\gamma$-glutamylhydroxamic acid; GSH, reduced glutathione. 
a very wide occurrence in nature. Its activity has been found in micro-organisms (Elliott, 1951; Fry, 1955), plants (Elliott, 1953), and a number of animal tissues from mealworm (Elliott, 1951) to human brain (Ota, 1959) and liver (Kennan \& Cohen, 1961). The enzyme probably plays a dual role in the economy of the animal, namely the synthesis of glutamine and the detoxication of ammonia. Since, as far as this synthetic reaction is concerned, these two functions are inseparable, it is possible, nonetheless, that one function or the other predominates in an animal or a particular organ of the animal. A survey of the distribution of this enzyme in the organs of different species of animals might help to elucidate the relative importance of its two functions. The findings could also shed some light on the relation of its distribution to the phylogenetic classification.

Allo- $\delta$-hydroxylysine inhibited the incorporation of amino acids into the protein of Ehrlich ascites tumor cells, and the inhibition was conceived as caused by an inhibition of glutamine synthesis (Rabinovitz et al., 1957). Therefore, the effect of this compound in vitro on the activity of glutamine synthetase of normal tissues was investigated, and the mode of its action was studied.

\section{MATERIALS AND METHODS}

\section{Animals}

The animals used in this study were as follows: the ox (Bos taurus), the pig (Sus domesticus), the rabbit (Oryctolagus cuniculus), the sheep (Ovis aries), the mink (Mustela vison), the rat (Rattus norvegicus), the chick (Gallus domesticus), the young pigeon (Columba livia), the young duck (Anas platyrhynchos), the young goose (Anser anser), the painted turtle (Chrysemys picta), the garter snake (Thamnophis sirtalis), the red-spotted newt (Diemictylus viridescens), the bullfrog (Rana catesbeiana), the bluegill (Lepomis macrochirus), the black crappie (Pomoxis nigromaculatus), and the ciliated protozoan (Tetrahymena pyriformis). Except for the last one mentioned, the organs or portions thereof were removed as soon as possible after the animals were killed, and they were frozen and stored at $-30^{\circ} \mathrm{C}$. T. pyriformis, grown in a peptone-glucose-acetate medium, was a gift of Dr. James F. Hogg.

\section{Chemicals}

Monosodium L-glutamate and GSH were purchased from the Nutritional Biochemicals Corporation; hydroxylamine hydrochloride and 2-mercaptoethanol from the Eastman Organic Chemicals; L-cysteine, BAL, and HL from the Mann Research Laboratories; and ATP from the Schwarz BioResearch, Inc. GHA was synthesized according to Roper \& McIlwain (1948) and recrystallized (four times) to a constant molar extinction coefficient by the ferric chloride reagent (Lipmann $\&$ Tuttle, 1945). This sample gave a molar extinction coefficient of 520. Another sample of GHA purchased from the Sigma Chemical Co. (Lot No. G101B-79) and labeled as 98 per cent pure gave a molar extinction coefficient of only 160 . The discrepancy has not been resolved, but the Sigma product was not used. 


\section{Assay procedure for glutamine synthetase}

Homogenates of tissues were prepared in distilled water with an all-glass homogenizer of the Potter-Elvehjem type and to contain approximately $40 \mathrm{mg}$ tissue per $\mathrm{ml}$ homogenate. Into a $25 \mathrm{ml}$ Erlenmeyer flask were introduced monosodium L-glutamate, $200 \mu$ moles; $\mathrm{NH}_{2} \mathrm{OH} . \mathrm{HCl}$ (freshly neutralized to $\mathrm{pH} 7.2$ with $\mathrm{NaOH}$ ), $200 \mu$ moles; $\mathrm{MgCl}_{2}, 40 \mu$ moles; L-cysteine, $50 \mu$ moles; ATP (freshly neutralized to $\mathrm{pH} 7.2$ with $\mathrm{NaOH}$ ), $20 \mu$ moles; tris-(hydroxymethyl)aminomethane

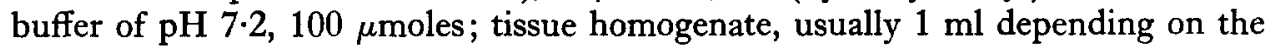
activity, and water to a final volume of $4.5 \mathrm{ml}$. The final $\mathrm{pH}$ should be between $7 \cdot 1$ and $7 \cdot 3$. ATP was added last to start the reaction. Another flask serving as the control was included for each tissue assayed and contained all the components listed above but ATP. The control with $\mathrm{NH}_{2} \mathrm{OH}$ omitted gave a slightly lower optical density reading than that with either ATP or glutamate omitted, the latter two being equal; for economic reasons, ATP was omitted from the controls in the routine assay. The flasks were placed in a Dubnoff metabolic shaking incubator and maintained at $37^{\circ} \mathrm{C}$ for $15 \mathrm{~min}$ with constant shaking. At the end of the incubation period, $0.5 \mathrm{ml}$ of $50 \%$ trichloroacetic acid was added to each flask. Four $\mathrm{ml}$ of the acid filtrate were used for the color development (Lipmann \& Tuttle, 1945) by adding to it $1 \mathrm{ml}$ each of $3 \mathrm{~N} \mathrm{HCl}$ and of $5 \% \mathrm{FeCl}_{3} \cdot 6 \mathrm{H}_{2} \mathrm{O}$ in $0 \cdot 1$ $\mathrm{N} \mathrm{HCl}$. The optical density readings were measured with a Coleman Jr. spectrophotometer. The color complex in the presence of the yellow color of $\mathrm{FeCl}_{3}$ gave a black tea color, which showed a maximum absorption near $510 \mathrm{~m} \mu$.

One unit of enzyme activity is defined as the amount of enzyme that will cause the formation of $1 \mu$ mole of GHA per hour at $37^{\circ}$. The tissue activity is expressed as units per $\mathrm{g}$ of the tissue, and the specific activity as units per mg protein.

\section{Other methods}

Protein was determined by the method of Lowry et al. (1951). Glutamine was estimated by difference in terms of ammonia between the unhydrolyzed and the hydrolyzed aliquots of the sample. Hydrolysis of glutamine was carried out in $10 \%$ trichloroacetic acid at $70^{\circ}$ for $90 \mathrm{~min}$ (Harris, 1943). Ammonia was determined by the phenol-hypochlorite reagent (Brown et al., 1957) after microdiffusion (Conway, 1962).

\section{RESULTS AND DISCUSSION}

\section{Evaluation of the assay method for glutamine synthetase}

A comparative study of this kind requires a satisfactory procedure for assaying the enzyme activity in tissue homogenates. The rat liver homogenate was chosen as the frame of reference to find the optimal conditions for such an assay. Although the amount of IP, ADP, or glutamine formed in a given time can be determined as a measure of the enzyme activity, it is difficult to determine any one of these compounds either accurately or conveniently. Because of a considerable breakdown of ATP by the tissue homogenate in the absence of glutamine synthesis, prior incubation with ATP, advantageous in the purified glutamine synthetase preparation 
(Boyer et al., 1959), could not be used. Consequently, the determination of IP or ADP in the reaction mixture would not give reliable results. Likewise, the determination of small amounts of glutamine formed in the presence of substrate quantities of ammonia poses a similar problem. The ability of the enzyme to catalyze a similar reaction in which hydroxylamine replaces ammonia has, however, been utilized as a means to assay the enzyme activity (Speck, 1949). In this instance, the product formed instead of glutamine is GHA, which can be determined conveniently by the method of Lipmann \& Tuttle (1945). The relatively low extinction coefficient of the hydroxamate- $\mathrm{FeCl}_{3}$ color complex mentioned before appears to be the only drawback in using the hydroxamate as a measure of the enzyme activity.

Stability of the enzyme in homogenates. Freshly frozen tissues, stored at $-30^{\circ} \mathrm{C}$ for a year, retained glutamine synthetase activity. Homogenates prepared in distilled water, however, lost the enzyme activity in relatively short times even at the same temperature. Table 1 shows the stability of the enzyme in rat liver homogenates

TABle 1-STability to storage of glutamine SYNThETASE IN RAT Liver homogenate

The values are expressed in per cent of the activity of the freshly prepared homogenate. Those in Column (1) represent storage in a series of tubes, each one thawed only once on the day of assay, while those in Column (2) represent storage in a single flask thawed each time assay was done.

\begin{tabular}{rcrc}
\hline \multirow{2}{*}{ Days of storage } & \multicolumn{2}{c}{ At $-30^{\circ}$} & \\
\cline { 2 - 3 } & $(1)$ & $(2)$ & \\
\hline 1 & 97.5 & & 86.1 \\
2 & 93.4 & & 83.7 \\
3 & & 93.6 & 77.3 \\
6 & & & 63.3 \\
8 & 92.8 & 91.1 & \\
10 & & & 55.6 \\
13 & 91.9 & 88.3 & 48.5 \\
17 & & & \\
20 & 89.6 & 80.8 & 43.5 \\
24 & 84.5 & 76.1 & \\
41 & & & \\
\hline
\end{tabular}

stored at $-30^{\circ} \mathrm{C}$ and at $5^{\circ} \mathrm{C}$ for different lengths of time. The enzyme activity deteriorated appreciably when stored at $5^{\circ}$ even for one day, but it was stable for a slightly longer period when kept at $-30^{\circ}$. The loss in activity on storage occurred at a faster rate in the first few days than afterwards.

The $p H$ optimum. The optimal $\mathrm{pH}$ for the enzyme in rat liver homogenate was

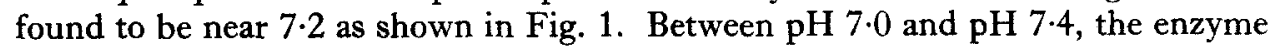
activity was little affected by $\mathrm{pH}$ changes. But a definite decrease in the enzyme activity occurred when the $\mathrm{pH}$ was lowered below 6.8 or raised above $7 \cdot 4$. 
The optimal concentrations of the substrates. The effect on the enzyme activity of varying concentrations of glutamate, hydroxylamine, $\mathrm{ATP}$, and $\mathrm{MgCl}_{2}$ in the reaction mixture has been investigated. The concentration of each of these

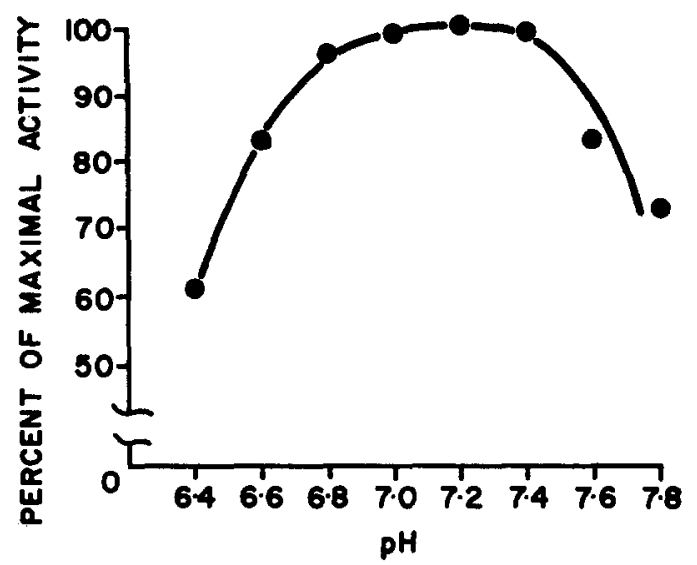

FIG. 1. The dependence of glutamine synthetase activity in rat liver homogenate on $\mathrm{pH}$ of the reaction mixture.

compounds that would give the maximal enzyme activity has been given in the "Assay Procedure" in the preceding section.

Relative effectiveness of the sulfhydryl compounds. Glutamine synthetase has been shown to require a sulfhydryl compound for its optimal activity (Speck, 1947; Elliott, 1953), and likewise to be inhibited by $p$-chloromercuribenzoate (Elliott, 1951; Fry, 1955). A comparison is made of the relative effectiveness of a few sulfhydryl compounds in fulfilling this requirement. Fig. 2 shows these results. The molar concentrations of the sulfhydryl compounds in the reaction mixture are shown on the abscissa on a logarithmic scale. The synthetase activity obtained with the optimal concentration of L-cysteine is designated as 100 on the ordinate, and the activities obtained with other concentrations of cysteine and of other sulfhydryl compounds are expressed as percentages of this value. In the absence of any added sulfhydryl compound, only 30 per cent of the optimal activity was obtained. 2-Mercaptoethanol, which was as effective as cysteine for a purified glutamine synthetase preparation from pea seedlings (Levintow \& Meister, 1954), was only 75 per cent as effective for the enzyme in a rat liver homogenate. The effectiveness of GSH lay somewhere between cysteine and 2-mercaptoethanol on a molar basis. Yet, the optimal concentration of these three compounds was essentially the same. Perhaps a difference of this magnitude is not uncommon. On a molar basis, however, BAL was 100 times as effective as cysteine. Obviously, the extremely high effectiveness of BAL cannot be explained on the number of sulfhydryl groups the molecule possesses. This compound might, nevertheless, play a role in glutamine synthesis similar to the one proposed by Fluharty \& Sanadi (1961) in oxidative phosphorylation. 
High concentrations (above $4.4 \times 10^{-2} \mathrm{M}$ in the reaction mixture) of cysteine or 2-mercaptoethanol interfered with the hydroxamate- $\mathrm{FeCl}_{3}$ color reaction. Cysteine formed a greenish brown color with $\mathrm{FeCl}_{3}$, and 2-mercaptoethanol reduced the intensity of the hydroxamate- $\mathrm{FeCl}_{3}$ color complex.

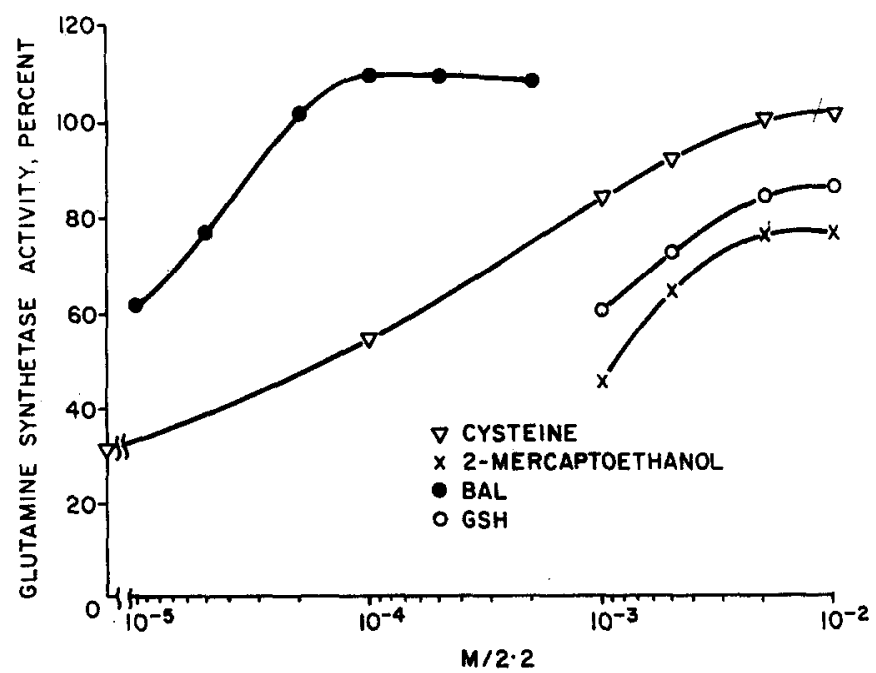

FIG. 2. The relative effectiveness of sulfhydryl compounds in activating glutamine synthetase in rat liver homogenate. The molar concentration of each compound in the reaction mixture is shown on the abscissa on a logarithmic scale. The enzyme activity is expressed on a per cent basis on the ordinate.

Proportionality of GHA formation to enzyme concentration. Under the optimal conditions for assaying the enzyme activity, the formation of GHA with varying amounts of rat liver at two time intervals is shown in Fig. 3. A linear relationship between GHA formation and enzyme concentration could be obtained only when the quantities of the GHA formed were no more than $1 \mu$ mole per assay flask (containing $4.5 \mathrm{ml}$ of the reaction mixture) in either 10 or $15 \mathrm{~min}$ of incubation. Beyond this limit the relationship was no longer linear. Dialysis of the homogenate did not improve the situation appreciably. The apparent inhibition observed with larger amounts of liver tissue or with longer time of incubation seems to be caused by the accumulation of ADP, which is inhibitory in the forward reaction (Elliott, 1951; Fry, 1955). Presumably the amounts of ADP formed in the reaction alone were insufficient to alter the rate of synthesis. If we take into account, however, the activity of various ADP-forming enzyme systems such as adenosinetriphosphatase and phosphokinases in the liver, the amounts of ADP formed in all these reactions would be adequate to inhibit the rate of glutamine or GHA synthesis. This points up a problem in assaying an enzyme activity in the homogenate, which does not exist with a purified enzyme preparation. Hence in the routine assay, the amount of tissue added was such that this limit of $1 \mu$ mole was not exceeded. A tissue activity of less than 10 units per $g$ could not be determined accurately. 
Therefore, the activity of 10 units per $g$ was chosen as the lower limit of the assay. Subsequently, the observation was made that deoxycholate, when added to the reaction mixture in optimal concentrations, would inhibit the hydrolysis of ATP by other enzyme systems in the microsome fraction of a rat liver homogenate, but

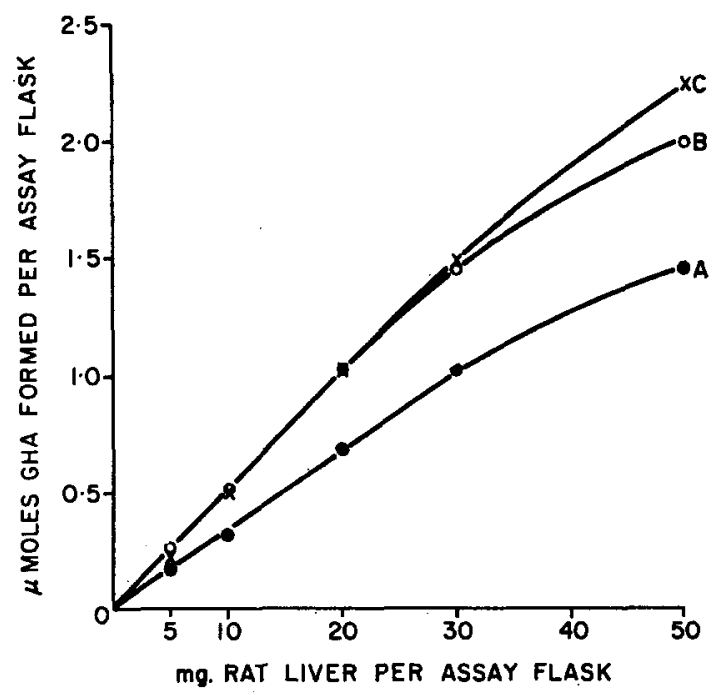

FIG. 3. The formation of $\gamma$-glutamylhydroxamate in rat liver homogenate under the optimal conditions of assay. A, $10 \mathrm{~min}$ incubation; B, $15 \mathrm{~min}$ incubation; C, $15 \mathrm{~min}$ incubation with the homogenate dialyzed against saline at $5^{\circ}$ for $24 \mathrm{hr}$.

would not inhibit glutamine synthesis. Furthermore, in this system with deoxycholate, the molar quantity of ATP disappearing approximated that of GHA synthesized. Conceivably, addition of an optimal amount of deoxycholate to the reaction mixture could maintain the initial rate of glutamine synthesis for a longer period of time. Deoxycholate was not, however, included in the reaction mixture in the routine assay.

\section{Distribution}

The optimal conditions, such as the $\mathrm{pH}$ and the concentrations of the substrates in the reaction mixture, were established for the assay with the rat liver homogenate as the frame of reference. Conceivably, the same set of conditions may not be optimal for the enzyme from a different organ or from a different species. Since it is not practical to establish a set of optimal conditions for the enzyme from each of the organs assayed, the results in the following table may not be strictly comparable in every case. This seems particularly true when a comparison is made between the activity of one organ of a species and that of another organ of another species. Despite these reservations, the procedure is still a useful means to get valuable information for a study of this kind. 
The distribution of glutamine synthetase in some twelve tissues of seventeen species of vertebrates (seven species of mammals, four species of birds, two species each of reptiles, amphibians and fishes) and one species of protozoan is presented in Table 2. The data are expressed in terms of the tissue activity and of the specific activity. The latter is more meaningful for comparison of activities in different tissues having different protein contents. For example, the tissue activity of snake liver was much higher than that of snake brain, but the specific activities of these two tissues were essentially the same. Nevertheless, the results in this table are discussed with an emphasis on comparing the enzyme activity in a certain tissue of all species examined rather than in various tissues of a given species.

Brain. Brain was unique in that it possessed the enzyme activity in all vertebrate species used, and that in the lower animals (ureotelic reptiles, amphibians and fishes), it became the only tissue to possess the enzyme activity. In general, the brains of the lower animals had higher activities than those of the higher animals. In fact, the highest specific activity observed in any tissue occurred in the brain of the bluegill. The two major divisions of the brain, the cerebrum and the cerebellum, were often used to assay the enzyme activity separately. In the lower animals, however, because of the smallness of the brain the entire tissue was used to assay the activity as a whole. When separate assays were done, the activities in the cerebrum and in the cerebellum were always different, with the exception of the turtle. In the mammals, excluding the rat, the activity in the cerebrum was always greater than that in the cerebellum. In the birds, the reverse was true. Actually in the pigeon, the activity in the cerebrum was so low that it was no longer detectable.

Apparently, brain is more susceptible to ammonia poisoning than any other tissue. High concentrations of blood ammonia lead to coma and convulsions in man (Seegmiller et al., 1954; McDermott \& Adams, 1954). Not only is the brain affected by the ammonia concentration in the circulation, but the brain tissue itself forms ammonia in vitro (Weil-Malherbe, 1950; Tsukada \& Takagaki, 1954). Thus, it is essential for the brain to have some mechanism by which ammonia can be effectively detoxicated. Perhaps the three most effective enzyme systems engaging in the removal of ammonia are glutamine synthetase, carbamyl phosphate synthetase, and glutamic dehydrogenase. Carbamyl phosphate synthetase has not been described thus far in brain. Although glutamic dehydrogenase has been determined in monkey and rabbit brains (Robins et al., 1956; Strominger \& Lowry, 1955), a comparative study of its distribution in brain and other tissues of a larger number of animal species appears to be lacking, and the relative importance of its role in ammonia detoxication cannot be commented on at present. The fact that brain always contains glutamine synthetase suggests that the enzyme plays an important role in the removal of ammonia from this tissue. Furthermore, the glutamic acid and glutamine contents in brain of a number of mammalian and avian species are quite similar (Waelsch, 1951). As shown in this study, however, glutamine synthetase activity was quite different in brain of various species. The enzyme activity probably serves as a regulatory mechanism for the constancy of 
GLUTAMINE SYNTHETASE

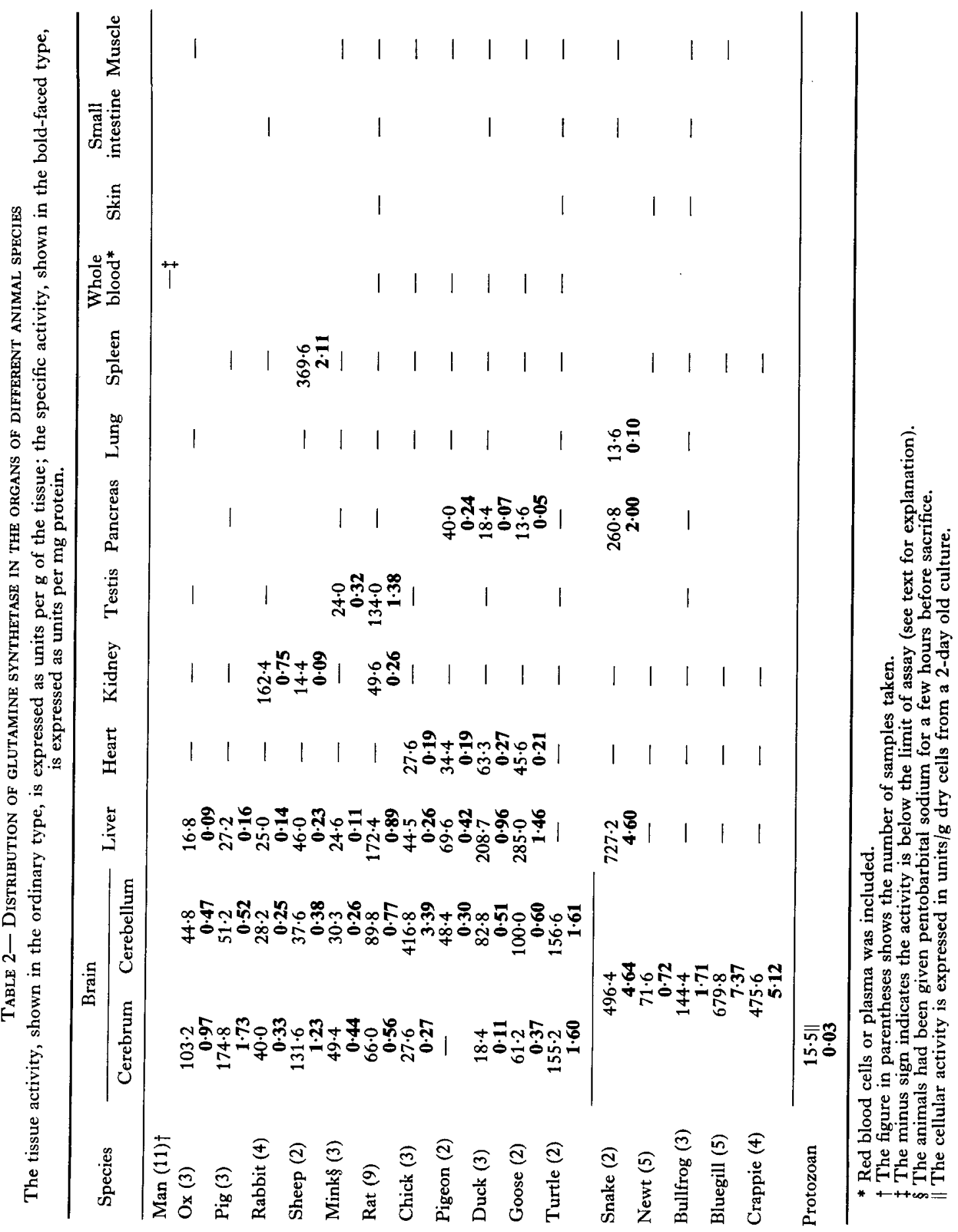


glutamic acid and glutamine contents in brain. Conceivably, the enzyme could also control the levels of ATP and ADP in this tissue.

Presumably in the ammonotelic fishes and in the ureotelic amphibians and reptiles, glutamine synthesis taking place in the brain is adequate to meet the demand for glutamine in the body. In the higher animals, the greater demand for glutamine is met by shifting the major site of synthesis from brain to other organs of the body. This can be illustrated with the rat as an example. The total activity in each of the four organs can be calculated from the tissue activity and the weight of each organ as follows: brain (cerebrum plus cerebellum) 118, liver 1860, kidneys 104 , and testes $416 \mu$ moles GHA synthesized per organ per hr. Hence, a $300 \mathrm{~g}$ rat has the potential to synthesize 60 mmoles of GHA or glutamine per day. Of this amount, only 2.8 mmoles or 4.7 per cent comes from brain. Consequently, glutamine synthetase activity in the brain of higher animals serves mainly to maintain and regulate the balance of the glutamic acid-glutamine system in this tissue and contributes relatively little to the overall demand for glutamine in the body. This hypothesis is further strengthened by the observation that, although glutamine synthetase in rat liver was responsive to tumor growth and nutritional status, the enzyme in rat brain was not ( $\mathrm{Wu}$, unpublished).

The value of 60 mmoles of GHA or glutamine synthesized per day for a $300 \mathrm{~g}$ rat calculated above may be compared with the values of 1.8 and 0.38 mmoles of GHA or glutamine synthesized per day, the maximal capacity for the brain of a $300 \mathrm{~g}$ bluegill and bullfrog, respectively. Such a comparison shows that the demand for glutamine in the higher animals is very much greater than that in the lower animals. Furthermore, the extremely low overall capacity for glutamine synthesis in the fishes appears to have little correlation to ammonotelism, for an even lower capacity was found in the largely ureotelic bullfrog.

Liver. Second only to brain in the frequency of occurrence of glutamine synthetase is liver. The enzyme was found in liver of all species above the reptilian level on the phylogenetic scale. A difference has been observed between the liver of a chelonian reptile (turtle) and that of an ophidian reptile (snake). The ureotelic turtle did not possess glutamine synthetase in liver, nor in any other tissue but brain. In this respect it retained the trait of its ureotelic amphibian ancestors. The uricotelic snake, on the other hand, possessed the enzyme not only in the liver but also in other tissues. Furthermore, glutamine synthetase activity in the snake liver was the highest of all livers. By and large, the enzyme activity in the liver of uricotelic animals (snake and birds) was considerably higher than that of ureotelic mammals. This difference in liver activity can be explained on the basis of ureotelism and uricotelism in these animals. In the uricoteles, uric acid forms the bulk of nitrogenous end products in the excreta, and for each mole of uric acid excreted 2 moles of glutamine are consumed (Levenberg et al., 1956). Obviously, if everything else renains the same, the uricoteles need considerably more glutamine than the ureoteles, which require no direct participation of glutamine in the synthesis of urea for excretion. Hence, the higher glutamine synthetase activity in liver of the uricoteles appears to be a metabolic necessity geared to cope with the greater demand for 
glutamine for uric acid synthesis. In this connection the lack of a measurable activity of carbamyl phosphate synthetase in liver of non-ureoteles (Cohen \& Brown, 1960) would give glutamine synthetase the important role of detoxicating ammonia in these animals.

Evidence that glutamine synthetase in liver of ureoteles can also play an important role in the removal of ammonia can be found in the work of Duda $\&$ Handler (1958), who showed that 80 per cent of the intravenously administered ammonia was converted to glutamine in $30 \mathrm{~min}$ in the rat. On the other hand, Kennan \& Cohen (1961), basing their calculations on the activities of ammoniafixing enzyme systems in liver, showed that glutamine synthesis would have little potential ability for ammonia detoxication in man. The high efficiency of glutamine synthesis for ammonia removal in the rat is probably due to the very high glutamine synthetase activity in liver of this species. As can be seen in Table 2 , the activity in liver of the rat was three to ten times as high as that of any other mammal examined. The activity in the human liver was much lower than the activity in the rat liver (Kennan \& Cohen, 1961).

An effort was made to examine if the variability of glutamine synthetase activity in liver of different species of animals could be correlated to the free glutamine content of this tissue. Since in the lower animals there was no detectable enzyme activity in liver, the situation offered an opportunity to learn to what extent the enzyme activity in brain contributed to the maintenance of the glutamine level in liver and possibly in other tissues of the body. Table 3 presents the glutamine content in the tissues of some animals. A comparison of the results in this and the preceding tables shows that no correlation existed between the glutamine content and glutamine synthetase activity of the liver. For example, the synthetase activity in the pig liver was quite comparable with that in the mink liver, but the glutamine content was twice as high in the latter as in the former. The synthetase activity in the snake liver was about forty-three times that of the ox liver, and yet the glutamine content in the snake liver was the same as that in the ox liver. Neither can a correlation between the liver glutamine content and the brain activity be discerned in those animals where glutamine synthetase activity could be found in brain only. The liver glutamine content of the black crappie was much lower than that of the bullfrog, but the enzyme activity in the brain of the former was much higher than that of the latter. In general, the glutamine content in liver of different species of animals is relatively constant, in view of the vast difference in the synthetase activity in liver of these animals. On the other hand, the plasma glutamine concentration appears to depend on the enzyme activity of the liver. In the order of increasing plasma glutamine level, the pigeon, the rat, and the goose also held the same order in their enzyme activity in liver. A definite correlation, however, cannot be established until a larger number of species has been examined more completely.

Other tissues. The distribution of glutamine synthetase in other tissues of animals has been studied from their positions in phylogeny. The occurrence of the enzyme in heart tissue appears to be a characteristic of birds, because the enzyme activity was not measurable in this tissue of mammals nor of reptiles. But the 
presence of the enzyme in pancreas seems to be limited to birds and snakes. Whether the association of the pancreatic enzyme with uricotelism is fortuitous or by design cannot be known. Glutamine synthetase was not found in kidney of any animals below the level of mammals, though even in some mammals this tissue contained no detectable enzyme activity. The same may be said of testis, but with a

TABle 3-Glutamine CONTENT IN LIVER, BRAin, AND PLASMa of SOME animals

\begin{tabular}{|c|c|c|c|}
\hline Species & $\begin{array}{c}\text { Liver } \\
\mu \text { moles/g }\end{array}$ & $\begin{array}{c}\text { Brain } \\
\mu \text { moles } / g\end{array}$ & $\begin{array}{c}\text { Plasma } \\
\mu \mathrm{mples} / 100 \mathrm{ml}\end{array}$ \\
\hline$O x$ & $\begin{array}{c}3 \cdot 17(2)^{*} \\
(3 \cdot 05-3 \cdot 30) \dagger\end{array}$ & & \\
\hline Pig & $\begin{array}{c}1 \cdot 86(2) \\
(1 \cdot 59-2 \cdot 12)\end{array}$ & & \\
\hline Sheep & $\begin{array}{c}2 \cdot 25(2) \\
(1 \cdot 95-2 \cdot 54)\end{array}$ & & \\
\hline Mink & $\begin{array}{c}3 \cdot 74(2) \\
(3 \cdot 65-3 \cdot 83)\end{array}$ & $\begin{array}{c}7 \cdot 68(2) \\
(6 \cdot 95-8 \cdot 40)\end{array}$ & \\
\hline Rat & $\begin{array}{r}5.96(15) \\
(5.02-6.93)\end{array}$ & $\begin{array}{c}5 \cdot 15(7) \\
(4 \cdot 69-6 \cdot 34)\end{array}$ & $\begin{array}{c}70 \cdot 2(10) \\
(61 \cdot 8-76 \cdot 9)\end{array}$ \\
\hline Pigeon & & & $48 \cdot 1(1)$ \\
\hline Goose & & & $\begin{array}{c}95 \cdot 3(2) \\
(74 \cdot 7-115 \cdot 9)\end{array}$ \\
\hline Snake & $\begin{array}{c}3 \cdot 00(3) \\
(2 \cdot 17-3 \cdot 77)\end{array}$ & & \\
\hline Newt & $\begin{array}{c}1.55(2) \\
(1.26-1.84)\end{array}$ & & \\
\hline Bullfrog & $\begin{array}{c}2 \cdot 45(3) \\
(2 \cdot 17-2 \cdot 83)\end{array}$ & & \\
\hline Crappie & $\begin{array}{c}0.94(3) \\
(0.84-1.11)\end{array}$ & & \\
\hline
\end{tabular}

* The number of samples analyzed.

$\dagger$ The range.

$\$$ Same as footnote $\S$ of Table 2 .

small number of species examined no definite statement should be made about this tissue. Unusual is the localization of glutamine synthetase in the snake lung and in the sheep spleen, because the enzyme was not found in these two tissues of any other species. Furthermore, the enzyme activity in the sheep spleen was the highest ever encountered in a mammalian tissue. This fact suggests a very rich mammalian source of the enzyme for detailed study. Finally, no measurable enzyme activity occurred in skeletal muscle, small intestine, skin, or whole blood, including red cells and plasma, of the many species used.

In summary, the observations described above indicate that glutamine synthetase is widely distributed in tissues of the vertebrates, and it is ubiquitous in the sense that it can always be found in at least one tissue (brain) of a given species. 
The enzyme plays an important role in the detoxication of ammonia in many species of animals, and it is responsible for the balance of glutamic acid-glutamine system in the brain. Its distribution shows some definite relations to the pattern of nitrogen excretion and to phylogeny. Hence, it is possible to predict with some certainty the presence or the absence (below the limit of assay) of the enzyme in a certain tissue of a certain species.

Protozoa. Tetrahymena pyriformis, the only unicellular animal used in this study, had a very low glutamine synthetase activity. Since the organism can grow in a synthetic medium containing no glutamine (Elliott, 1949), its ability to synthesize this compound at a rate commensurate with its needs cannot be questioned. De Mars (1958) and Fottrell \& Paul (1961) have shown that in the mammalian cell cultures the activity of glutamyl transferase, which appears to be very closely related to glutamine synthetase (Elliott, 1953), was greatly decreased when glutamine was added to the culture media. A similar inhibition by glutamine of glutamyl transferase in the germinating wheat embryo was observed by Rijven (1961). Since the protozoan cells used in the present study were grown in a peptone medium, which undoubtedly contained glutamine, the synthetase activity was probably inhibited. Had the protozoan cells been grown in a medium devoid of glutamine, the synthetase activity in these cells could have been much higher. Fry (1955) determined glutamine synthetase activity in a number of species of bacteria, and his results may be recalculated on a comparable basis to give 11 to $100 \mu$ moles of GHA synthesized/g dry weight cell extract/hr. Hence, the enzyme activity in the protozoan was lower than that in most of its plant counterparts and was comparable only with that of Lactobacillus casei.

\section{Inhibition by DL-allo- $\delta$-hydroxylysine}

Although the inhibitory effect of HL on the incorporation of amino acids into the protein of ascites tumor cells has been observed (Rabinovitz et al., 1957), the action of HL on glutamine synthesis in normal tissues has not been studied. A comparative study of its action on glutamine synthetase activity in different tissues from many species of animals would seem pertinent. The results presented below show that HL inhibited glutamine synthetase activity in vitro. When added to the reaction mixture to a final concentration of $1.1 \times 10^{-3} \mathrm{M}$ or $4.4 \times 10^{-3} \mathrm{M}$, HL inhibited the enzyme activity found in many organs of a number of species of animals (Table 4). The extent of inhibition is expressed as a percentage of the activity of the uninhibited control. The per cent inhibition by a given concentration of HL did not vary widely in the organs tested. Presumably the configuration of that part of the enzyme molecule acted upon by HL is similar in different species. The type of inhibition by HL was studied with a rat liver homogenate. The results, plotted according to Lineweaver \& Burke (1934), show that the inhibition by HL was non-competitive (Fig. 4). The apparent $K_{m}$ for glutamate estimated graphically was $1.1 \times 10^{-2} \mathrm{M}$, and the apparent $K_{i}$ for $\mathrm{HL}$ was $3.8 \times 10^{-3} \mathrm{M}$. Hence, the affinity of the enzyme for HL was nearly three times as great as that for glutamate. The $K_{m}$ value agrees very well with that obtained for the enzyme from Micrococcus 
pyogenes (Fry, 1955). But it was different from the values of $5.5 \times 10^{-2} \mathrm{M}$ for guinea pig kidney (Richterich-Van Baerle et al., 1957) and $2.7 \times 10^{-3} \mathrm{M}$ for pigeon liver (Speck, 1949). All these values were obtained with crude enzyme preparations.

TABLE 4-INHIBITION BY DL-ALLO- $\delta$-HYDROXYLYSINE OF GLUTAMINE SYNTHETASE IN VARIOUS ANIMAL TISSUES

\begin{tabular}{lcc}
\hline & \multicolumn{2}{c}{ Per cent inhibition } \\
\cline { 2 - 3 } Tissue & HL $=1 \cdot 1 \times 10^{-3} \mathrm{M}$ & $\mathrm{HL}=\mathbf{4 \cdot 4} \times 10^{-3} \mathrm{M}$ \\
\hline Pig brain & 50 & 78 \\
Rabbit kidney & 40 & 68 \\
Sheep spleen & 54 & 78 \\
Rat liver & 28 & 63 \\
Rat brain & 38 & 62 \\
Mouse testis & 47 & 80 \\
Pigeon heart & 23 & 50 \\
Snake pancreas & 34 & 67 \\
Bluegill brain & 44 & 73 \\
\hline
\end{tabular}

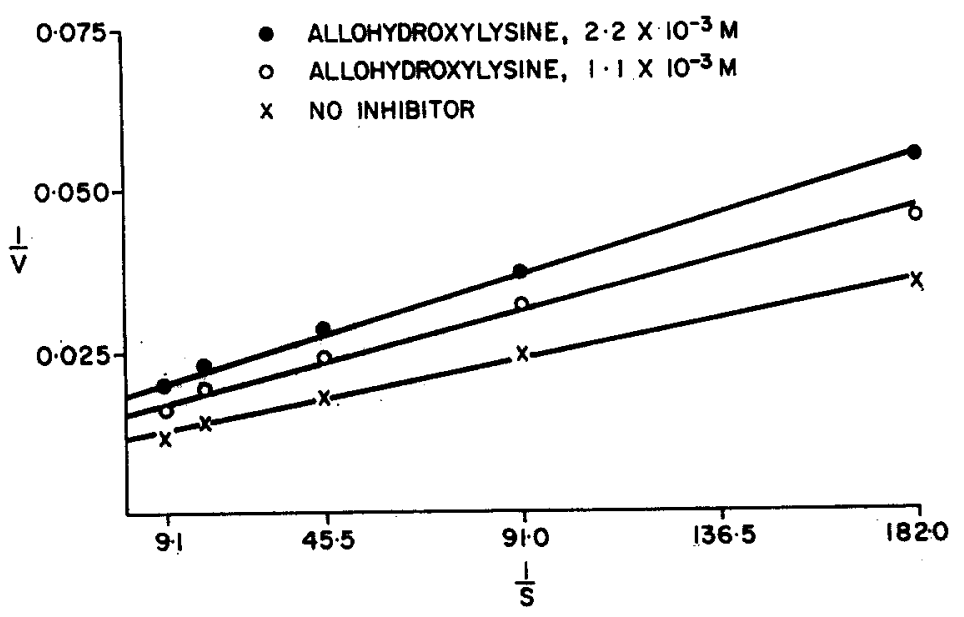

FIG. 4. The non-competitive inhibition of glutamine synthetase by DL-allo- $\delta$ hydroxylysine. The reciprocal of $S$, the molar concentration of glutamate in the reaction mixture, is plotted versus the reciprocal of $V$, the rate, expressed in $\mu$ moles, of the glutamylhydroxamate synthesized per $g$ rat liver per hour. The assay conditions were the same as described in the text except that cysteine was omitted from the reaction mixture.

\section{SUMMARY}

The optimal conditions for assaying glutamine synthetase activity in tissue homogenates have been investigated. 
Glutamine synthetase activity has been assayed in tissues of seven species of mammals, four species of birds, two species each of reptiles, amphibians, and fishes, and one species of Protozoa. The enzyme activity was found in the brain of all vertebrates examined. In the fishes, amphibians, and ureotelic reptiles, the brain was also the only organ in which the enzyme activity could be found. From the uricotelic reptiles to the mammals, the enzyme activity was present in the liver also. Its occurrence in the heart appears to be characteristic of the birds, and its presence in the kidney seems to be limited to some mammals. In addition, the enzyme activity was observed in the testis, spleen, lung, and pancreas of some species. It was not detected, however, in the blood, skeletal muscle, intestine, or skin of any species studied. These observations reveal a definite correlation between the distribution of glutamine synthetase and the phylogenetic classification. The significance of these findings is further interpreted in terms of the roles the synthetic reaction plays in the detoxication of ammonia, particularly in the brain, in the maintenance of balance of the glutamic acid-glutamine system, and in the pattern of nitrogen excretion.

No correlation between the glutamine content and the synthetase activity in liver of many species of animals can be discerned from this study.

The enzyme activity could be demonstrated also in the one species of Protozoa examined.

DL-Allo- $\delta$-hydroxylysine inhibited glutamine synthetase activity equally well in a variety of tissues from a number of species of animals. The inhibition was non-competitive with respect to glutamate.

Acknowledgements-The author wishes to acknowledge the technical assistance of Jaclin Christian. He also would like to express his appreciation for the cooperation of Peters Sausage Company and Steeb Brothers Packing House, both of Ann Arbor, Michigan, for the organs of the pig, the sheep and the ox; and of the Institute for Fisheries Research, Department of Conservation of the State of Michigan, for the black crappie and the bluegill. Thanks are also due to Peter M. Litchfield for a gift of the newt.

\section{REFERENCES}

Boyer P. D., Mrlls R. C. \& Fromm H. J. (1959) Hypotheses for and some kinetic studies with glutamine synthetase and acetate thiokinase. Arch. Biochem. Biophys. 81, 249-263.

Brown R. H., Duda G. D., Korkes S. \& Handler P. (1957) A colorimetric micromethod for determination of ammonia; the ammonia content of rat tissues and human plasma. Arch. Biochem. Biophys. 66, 301-309.

Cohen P. P. \& Brown G. W., Jr. (1960) Ammonia metabolism and urea synthesis. In Comparative Biochemistry (Edited by Florkin M. \& Mason H. S.), Vol. II, pp. 161-244. Academic Press, New York.

Conway E. J. (1962) Microdiffusion Analysis and Volumetric Error, 5th ed., pp. 90-97. Crosby Lockwood \& Son Ltd., London.

DE MARS R. (1958) The inhibition by glutamine of glutamyl transferase formation in cultures of human cells. Biochim. Biophys, Acta 27, 435-436.

Duda G. D. \& Handler P. (1958) Kinetics of ammonia metabolism in vivo. F. Biol. Chem. 232, 303-314.

Elliotr A. M. (1949) The amino acid requirements of Tetrahymena geleii (E). Physiol. Zool. 22, 337-345. 
Elliotr W. H. (1948) Adenosinetriphosphate in glutamine synthesis. Nature, Lond. 161, 128-129.

ElliotT W. H. (1951) Studies on the enzymic synthesis of glutamine. Biochem. F. 49, $106-112$.

ElLIOTT W. H. (1953) Isolation of glutamine synthetase and glutamotransferase from green peas. \%. Biol. Chem. 201, 661-672.

Flunarty A. L. \& SANADI D. R. (1961) On the mechanism of oxidative phosphorylation. II. Effects of arsenite alone and in combination with 2,3-dimercaptopropanol. F. Biol. Chem. 236, 2772-2778.

Fottrell P. \& Paul J. (1961) Studies on the mechanism controlling glutamyl transferase activity in mammalian cells. Biochem. F. 80, 17P.

FRY B. A. (1955) Glutamine synthesis by Micrococcus pyogenes var. aureus. Biochem. F. 59, 579-589.

Harris M. M. (1943) Studies regarding a glutamine-like substance in blood and spinal fluid, including a method for its quantitative determination. F. Clin. Invest. 22, 569-576.

Kennan A. L. \& Cohen P. P. (1961) Ammonia detoxication in liver from humans. Proc. Soc. Exp. Biol. Med. 106, 170-173.

Levenberg B., Hartman S. C. \& Buchanan J. M. (1956) Biosynthesis of the purines. X. Further studies in vitro on the metabolic origin of nitrogen atoms 1 and 3 of the purine ring. F. Biol. Chem. 220, 379-390.

Levintow L. \& Meister A. (1954) Reversibility of the enzymatic synthesis of glutamine. F. Biol. Chem. 209, 265-280.

Lineweaver H. \& Burke D. (1934) The determination of enzyme dissociation constants. 7. Amer. Chem. Soc. 56, 658-666.

Lipmann F. \& Tuttle L. C. (1945) A specific micromethod for the determination of acylphosphates. 7. Biol. Chem. 159, 21-28.

Lowry O. H., Rosebrough N. J., FarR A. L. \& Randall R. J. (1951) Protein measurement with the Folin phenol reagent. F. Biol. Chem. 193, 265-275.

McDermotr W. V., Jr., \& Adams R. D. (1954) Episodic stupor associated with an Eck fistula in the human with particular reference to the metabolism of ammonia. $\mathcal{F}$. Clin. Invest. 33, 1-9.

OTA T. (1959) Nitrogen metabolism of the brain. XXV. Activities of glutamine synthesis in the brain extracts of various animals. Okayama Igakkai Zasshi 71, 2133-2137; Chem. Abs. 54, 1877a (1960).

Rabinovitz M., Olson M. E. \& Greenberg D. M. (1957) $\delta$-Hydroxylysine-an inhibitor of glutamine and protein synthesis by the Ehrlich ascites carcinoma cell. Cancer Research 17, 885-889.

Richterich-Van Baerle R., Goldstein L. \& Dearborn E. H. (1957) Kidney glutaminases. III. Glutamine synthesis in the guinea pig kidney. Enzymologia 18, 327-336.

Rijven A. H. G. C. (1961) Regulation of glutamyl transferase level in germinating wheat embryos. Biochim. Biophys. Acta 52, 213-215.

Robins E., Roberts N. R., Eydt K. M., Lowry O. H. \& Smith D. E. (1956) Microdetermination of $\alpha$-keto acids with special reference to malic, lactic and glutamic dehydrogenases in brain. F. Biol. Chem. 218, 897-909.

Roper J. A. \& MCILwain H. (1948) Preparation and antibacterial action of some compounds structurally related to glutamic acid. Their application in microbiological determination of small quantities of glutamine. Biochem. F. 42, 485-492.

Seegmiller J. E., Schwartz R. \& Davidson C. S. (1954) The plasma "ammonia" and glutamine content in patients with hepatic coma. F. Clin. Invest. 33, 984-988.

SPECK J. F. (1947) The enzymatic synthesis of glutamine. F. Biol. Chem. 168, 403-404.

SPECK J. F. (1949) The enzymatic synthesis of glutamine, a reaction utilizing adenosine triphosphate. F. Biol. Chem. 179, 1405-1426. 
Strominger J. L. \& Lowry O. H. (1955) The quantitative histochemistry of brain. IV. Lactic, malic and glutamic dehydrogenases. F. Biol. Chem. 213, 635-646.

Tsukada Y. \& TAKagaki G. (1954) Ammonia formation systems in brain tissue. Nature, Lond. 173, 1138-1139.

WaElsch H. (1951) Glutamic acid and cerebral function. In Advances in Protein Chemistry (Edited by Anson M. L., Edsall J. T. \& Bailey K.), Vol. VI, pp. 299-341. Academic Press, New York.

Weil-Malherbe H. (1950) Significance of glutamic acid for the metabolism of nervous tissue. Physiol. Rev. 30, 549-568. 